\title{
Profil Saluran Pencernaan Itik Tegal Betina yang Diberi Pakan Tambahan Kombinasi Limbah Ekstraksi Daun Pepaya dan Bakteri Asam Laktat
}

\author{
A. Fandi, E. Suprijatna*, R. Muryani \\ Program Studi Peternakan, Fakultas Peternakan dan Pertanian, Universitas Diponegoro, Semarang 50275 \\ Dikirim 05 November 2018; Diterima 26 Desember 2018
}

\begin{abstract}
ABSTRAK
Penelitian ini bertujuan untuk mengkaji pengaruh pemanfaatan Limbah Ekstraksi Daun Pepaya (EDP) yang dikombinasikan dengan Bakteri Asam Laktat (BAL) sebagai pakan tambahan terhadap profil saluran pencernaan itik tegal. Penelitian ini menggunakan 96 itik tegal betina berumur 22 minggu dan diberi 4 macam perlakuan yang terdiri dari 4 ulangan pada tiap perlakuannya. Perlakuan pada pakan adalah $\mathrm{T} 0=$ Pakan basal, $\mathrm{T} 1=$ Pakan basal $+1 \%(\mathrm{EDP}+\mathrm{BAL}), \mathrm{T} 2=\mathrm{Pakan}$ basal $+2 \%($ EDP+BAL $)$, dan T3 = Pakan basal + 3\% (EDP+BAL. Parameter yang diamati adalah bobot relatif hati, usus halus, ventrikulus, panjang jejenum, ileum, duodenum dan sekum. Data yang diperoleh di analisis menggunakan analisis sidik ragam dan dilanjutkan dengan uji duncan. Hasil penelitian menunjukan penambahan EDP+BAL pada pakan tidak berpengaruh signifikan terhadap panjang dan bobot saluran pencernaan. Kesimpulan dari penelitian ini adalah penambahan limbah Ekstraksi Daun Pepaya dan Bakteri Asam Laktat tidak menambah atau mengurangi panjang dan bobot saluran pencernaan itik tegal betina umur 22-30 minggu.
\end{abstract}

Kata kunci: Ekstrak daun pepaya, Bakteri asam laktat, Itik tegal, Saluran pencernaan

\section{Digestive Track Profile Of Tegal Female Duck That Fed With Additional Combination Of Waste Of Papaya Leaf Extraction And Lactic Acid Bacteria}

\begin{abstract}
This study aims to examine the effect of the use of papaya leaf extract (EDP) combined with lactic acid bacteria (BAL) as an additional feed of the digestive tract profile of tegal ducks. This study used 96 female tegal ducks aged 22 weeks and given 4 types of treatment consisting of 4 replications in each treatment. The treatment of rations is $T 0=B a s a l$ feed, $T 1=$ Basalfeed $+1 \%(E D P+B A L), T 2=$ Basalfeed $+2 \%(E D P+B A L)$, and $T 3=$ Basal feed $+3 \%(E D P+B A L)$. The parameters observed were the relative weight of the liver, small intestine, gizzard and length of jejunum, ileum, duodenum, and cecum. The data obtained were analyzed by variance analysis with complete randomized design and Duncan test. The results of the study showed that the addition of $E D P+B A L$ in the feed did not significantly influence the length and weight of the digestive tract. The conclusion of this study is the addition of waste Extraction of Papaya Leaves and Lactic Acid Bacteria does not increase or decrease length and weight of digestive tract female tegal ducks 22-30 weeks age.
\end{abstract}

Keywords: Papaya leaf extract, Lactic acid bacteria, Tegal duck, Digestive tract

\section{PENDAHULUAN}

Peran peternakan itik sangatlah penting untuk menyediakan kebutuhan protein daging dan telur masyarakat Indonesia. Jumlah populasi itik di Indonesia tiga tahun terakhir 2015 sampai 2017 mengalami peningkatan dengan rata-rata jumlah peningkatan mencapai $4,7 \%$ dari total populasi, populasi per tahun 2017 mencapai 49.709 .403 ekor (Badan Pusat Statistikik, 2018).

Kendala yang sering dihadapi peternak itik di Indonesia adalah kelangkaan bahan pakan (Suprijatna et al., 2012) dan pengaruh buruk iklim tropis yaitu lingkungan dengan suhu tinggi (Tamzil, 2014). Pakan adalah hal yang paling penting dalam usaha ternak itik karena menjadi faktor keberhasilan yang mencapai 60$70 \%$ dari total biaya (Astuti, 2015).

Permasalahan efisiensi pakan dan kesehatan itik bisa diatasi menggunakan antibiotik, namun penggunaannya sudah dilarang karena dapat

*Penulis Korespondensi: Edjeng Suprijatna

Alamat: Jl. Prof. H. Soedarto, S.H., Tembalang Semarang, 50275

E-mail: edjengs@gmail.com menimbulkan residu dan resistensi terhadap mikroorganisme sehingga berbahaya jika dikonsumsi (PERMENTAN, 2017). Dewasa ini, dikembangkan alternatif produk additif pakan berupa prebiotik, probiotik dan sinbiotik sebagai pengganti antibiotik untuk menyeimbangkan mikrofilia pada usus (Dankowiakowska et al., 2013).

Prebiotik bisa dibuat dari tanaman dengan serat tinggi yang mengandung oligosakarida dan polisakarida rantai panjang (Wichienchot et al., 2011). Kandungan oligosakarida terdapat pada beberapa tanaman yaitu pitaya merah, pitaya putih dan pepaya (Khalili et al., 2014). Probiotik merupakan mikroorganisme yang bisa diperoleh dari Bakteri Asam Laktat (BAL) yang terdapat pada usus halus, bersifat menguntungkan ternak karena dapat meningkatkan kesehatan ternak dan meningkatkan efisiensi penggunaan pakan (Zurmiati et al., 2014). Penambahan probiotik ke dalam pakan efektif dalam meningkatkan kinerja usus dan kecernaan nutrisi pakan ayam (Mountzouris et al., 2010). Pemberian probiotik dapat mempengaruhi pertumbuhan vili-vili pada usus halus ayam (Kim et al., 2012). Bakteri asam laktat mengurai serat kasar yang tinggi menjadi asam lemak mudah 
terbang sehingga mengubah suasana menjadi asam, mengakibatkan aktivitas enzim meningkat (Kompiang, 2009).

Sinbiotik merupakan gabungan probiotik dan prebiotik yang berfungsi untuk mengoptimalkan fungsi saluran pencernaan dengan cara menyeimbangkan mikroflora yang ada pada saluran pencernaan (Bandyopadhyay dan Mandal, 2014). Saluran pencernaan merupakan bagian vital dalam proses mencerna pakan, Kondisi usus yang baik akan mengoptimalkan proses pencernaan pakan. Kondisi usus dipengaruhi oleh pakan dan bakteri yang hidup dalam saluran pencernaan. saluran pencernaan yang baik ditandai dengan perkembangan ukuran saluran dan perkembangan vili di dalam usus (Murwani, 2010).

Limbah Ekstraksi Daun Pepaya (EDP) mengandung oligosakarida yang tinggi, dengan dikombinasikan dengan bakteri asam laktat (BAL) diharapkan akan mampu berperan sebagai aditif untuk memperbaiki keseimbangan bakteri kecernaan lebih efektif dari pada pemberian prebiotik maupun probiotik secara terpisah. Menurut penelitian terdahulu oleh Yang et al., (2005), gabungan dari prebiotik dan probiotik sebagai sinbiotik mampu bekerja sinergis sehingga mampu meningkatkan ekosistem saluran usus dengan meningkatkan populasi probiotik dan aktivitas enzim pencernaan.

Tujuan dari penelitian ini adalah untuk mengkaji pengaruh penggunaan limbah (EDP) yang dikombinasi dengan (BAL) sebagai aditif pakan terhadap pertumbuhan saluran pencernaan yang dapat dilihat melalui profil saluran pencernaan itik. Hasil penelitian diharapkan dapat memberikan informasi pemanfaatan limbah EDP dan BAL sebagai additif pakan.

\section{MATERI DAN METODE}

Penelitian dilaksanakan pada bulan Oktober Desember 2017 di kandang panggung Laboratorium Produksi Ternak Unggas Fakultas Peternakan dan Pertanian Universitas Diponegoro Semarang.

Materi yang digunakan dalam penelitian ini adalah itik tegal yang dibeli dari peternak itik tegal di kabupaten Jepara Jawa Tengah sebanyak 96 ekor umur
22 minggu dengan bobot badan rata-rata $1412 \pm 175,12$ g pada tahap pendahuluan dan umur 30 minggu pada pengambilan data. Pakan yang digunakan terdiri dari bahan pakan jagung giling, tepung ikan, bungkil kedelai, bekatul, premix dan kombinasi EDP dengan BAL.

Kandang yang digunakan adalah jenis kandang panggung yang didalamnya dibagi lagi menjadi 16 bagian atau unit dengan ukuran pajang $1 \mathrm{~m}$ x lebar 90 $\mathrm{cm}$ dan tinggi $1 \mathrm{~m}$ dan setiap unit diisi 6 ekor itik. Peralatan yang digunakan berupa timbangan digital (ketelitian 0,001 g) ntuk menimbang bobot itik dan organ dalamnya, pita ukur (ketelitian $0,1 \mathrm{~cm}$ ) untuk mengukur panjang saluran pencernaan itik.

\section{Pembuatan Pakan Tambahan}

Bakteri asam laktat diisolasi dari sekum itik dan dimasukan dalam media MRS (de Man Rogosa and Sharpe) cair. Bakteri diinkubasi selama 24 jam pada suhu $37^{\circ} \mathrm{C}$ sampai bakteri tumbuh. Pengkulturan dilakukan pada media MRS agar yang ditambah $\mathrm{CaCO}_{3}$ $1 \%$ sebanyak $0,5 \mathrm{~g}$ dan diinkubasi lagi selama 24 jam pada suhu $37^{\circ} \mathrm{C}$. Bakteri yang memiliki ciri-ciri seperti bakteri asam laktat akan disubkultur di MRS cair dan diinkubasi selama 24 jam pada suhu $37^{\circ} \mathrm{C}$, kemudian dilakukan kultur lagi di agar. Bakteri akan encerkan lagi sebanyak 8 kali. Probiotik yang dihasilkan memiliki koloni sebanyak 2,1 x $10^{9} \mathrm{cfu} / \mathrm{ml}$.

Limbah EDP diperoleh dari limbah industri jamu PT. Borobudur Semarang. Sebelum dikombinasikan dengan BAL, probiotik dilakukan inkubasi dengan menambah $100 \mathrm{ml}$ akuades dengan 10 $\mathrm{ml}$ bakteri asam laktat selama 24 jam dengan suhu $37^{\circ} \mathrm{C}$. Jumlah perbandingan prebiotik dan probiotik yang dicampur adalah $3 \mathrm{~g}$ : $110 \mathrm{ml}$. Gabungan prebiotik dan probiotik diinkubasi selama 24 jam pada suhu $37^{\circ} \mathrm{C}$. Setelah diinkubasi, pengenceran dilakukan sebanyak 8 kali menggunakan $\mathrm{NaCl} 0,85 \%$ sehingga dihasilkan $2,1 \times 10^{9} \mathrm{CFU}$.

Kebutuhan perlakuan dengan dosis $1 \%, 2 \%$, dan $3 \%$ dari pakan dalam 1 hari dibutuhkan (EDP+BAL) sebanyak $216 \mathrm{~g}$, kemudian untuk menghasilkan (EDP+BAL) sebanyak $216 \mathrm{~g}$ dalam 1 hari, dilakukan pencampuran $216 \mathrm{~g}$ limbah ekstraksi daun pepaya

Tabel 1. Hasil Analisis Bahan Pakan Basal

\begin{tabular}{|c|c|c|c|c|c|c|c|}
\hline Bahan pakan & EM** & $\mathrm{PK}^{*}$ & SK* & $\mathrm{LK}^{*}$ & $\mathrm{Ca}^{*}$ & $\mathrm{P}^{*}$ & $\mathrm{Abu}^{*}$ \\
\hline & (kkal/kg) & & --- & --- & 7o----- & - & - \\
\hline Jagung & 3197,68 & 7,36 & 0,64 & 0,74 & 0,37 & 0,44 & 15,87 \\
\hline Bungkil Kedelai & 2985,01 & 46,02 & 2,48 & 0,71 & 0,60 & 0,25 & 27,19 \\
\hline Bekatul & 2404,86 & 7,80 & 15,3 & 3,67 & 0,002 & 0,62 & 19,87 \\
\hline MBM & 2769,00 & 52,34 & 5,4 & 9,08 & 2,37 & 1,89 & 15,32 \\
\hline Tepung Ikan & 3008,88 & 42,37 & 11,48 & 17,41 & 5,11 & 2,88 & 25,53 \\
\hline Mineral & 0,00 & 0,00 & 0,00 & 0,00 & 32,50 & 1,00 & 0,00 \\
\hline Limbah EDP & 727,45 & 11,82 & 14,33 & 0,43 & 5,51 & 0,17 & 59,64 \\
\hline
\end{tabular}

* Berdasarkan bahan kering udara

* Analisis proksimat dilaksanakan di Laboratorium Ilmu Nutrisi dan Pakan, Fakultas Peternakan dan Pertananian, Universitas Diponegoro, Semarang (2017)

** Berdasarkan rumus perhitungan dengan rumus balton: EM $(\mathrm{kkal} / \mathrm{kg})=40,81[0,87(\mathrm{PK}+2,25 \mathrm{x} \mathrm{LK}+\mathrm{BETN})+\mathrm{k}]$ yang disitasi Wijaya et al. (2017). 
Tabel 2. Komposisi dan kandungan nutrien pakan perlakuan

\begin{tabular}{|c|c|c|c|c|}
\hline \multirow{2}{*}{ Bahan pakan } & \multicolumn{4}{|c|}{ Perlakuan } \\
\hline & T0 & T1 & T2 & T3 \\
\hline Jagung & 52 & $\begin{array}{r}-(\%)---- \\
52\end{array}$ & 52 & 52 \\
\hline Bungkil Kedelai & 23 & 23 & 23 & 23 \\
\hline Bekatul & 8 & 8 & 8 & 8 \\
\hline Meat Bone Meal (MBM) & 6 & 6 & 6 & 6 \\
\hline Tepung Ikan & 6 & 6 & 6 & 6 \\
\hline Mineral & 5 & 5 & 5 & 5 \\
\hline$(\mathrm{EDP}+\mathrm{BAL})$ & 0 & 1 & 2 & 3 \\
\hline Total & 100 & 101 & 102 & 103 \\
\hline Kandunan nutrien & & & & \\
\hline EM (kkal/kg) & 2888,41 & 2867,01 & 2846,03 & 2825,46 \\
\hline Protein kasar (\%) & 20,71 & 20,63 & 20,54 & 20,46 \\
\hline Serat Kasar (\%) & 3,14 & 3,25 & 3,36 & 3,46 \\
\hline Lemak Kasar (\%) & 2,43 & 2,41 & 2,39 & 2,37 \\
\hline $\mathrm{Ca}(\%)$ & 2,40 & 2,43 & 2,46 & 2,49 \\
\hline $\mathrm{P}(\%)$ & 0,67 & 0,66 & 0,66 & 0,65 \\
\hline
\end{tabular}

Hasil analisis Laboratorium Ilmu Nutrisi dan Pakan, Fakultas Peternakan dan Pertanian, Universitas Diponegoro, Semarang (2017).

dengan probiotik yang terdiri dari 7,2 $\mathrm{g}$ aquades dan $720 \mathrm{ml}$ bakteri asam laktat. Kombinasi yang dihasilkan antara limbah EDP dan BAL berbentuk lembek.

Hasil analisa bahan pakan basal disajikan dalam Tabel 1. Komposisi dan kandungan nutrien dalam pakan disajikan dalam Tabel 2. Standar mutu bahan pakan disajikan dalam Tabel 3. Kandungan oligosakarida limbah ekstraksi daun pepaya disajikan dalam Tabel 4.

$\underline{\text { Tabel 3. Standar dan mutu pakan itik petelur fase layer }}$

\begin{tabular}{llr}
\hline \hline Parameter & \multicolumn{2}{c}{ Persyaratan } \\
\hline Kadar Air $(\%)$ & Maks. & 14,0 \\
Protein Kasar $(\%)$ & Min. & 15,0 \\
Lemak Kasar $(\%)$ & Maks. & 7,0 \\
Serat kasar $(\%)$ & Maks. & 8,0 \\
Kalsium $(\%)$ & & $3,0-4,0$ \\
Fosfor Total $(\%)$ & & $0,60-1,00$ \\
Aflatoxin $(\mu \mathrm{g} / \mathrm{Kg})$ & Maks. & 20,0 \\
Energi Metabolis $(\mathrm{ME})$ & Min. & 2650 \\
$($ kkal/kg) & & \\
Standar Nasional Indonesia (2006) &
\end{tabular}

Tabel 4. kandungan oligosakarida daun pepaya

\begin{tabular}{lcc}
\hline \hline Parameter & Hasil & Metode Uji \\
\hline & $---\%----$ & \\
Maltopentosa & 0,03 & \\
Rafinosa & 0,49 & \\
Manosa & 0,01 & HPLC \\
Sukrosa & 1,91 & \\
Arabinosa & 0,34 & \\
Glukosa & 0,28 & \\
\hline
\end{tabular}

Hasil analisis Balai Penelitian Ternak Bogor, 2018

\section{Tahap Penerapan Perlakuan dan Pengumpulan Data}

Hasil kombinasi limbah EDP dan BAL yang telah diinkubasi ditambahkan ke ransum dengan dosis
$0 \%, 1 \%, 2 \%$ dan $3 \%$ dari ransum yang diberikan (150 g/ekor/hari). Pakan yang diberikan berbentuk mash, setelah dicampur dengan kombinasi limbah EDP+BAL pakan dicampur dengan air sampai pakan berbentuk lembek. Dosis yang ditambahkan dalam ransum adalah:

- dosis $0 \%=150 \mathrm{~g}$ pakan basal/ekor/hari

- dosis $1 \%=150 \mathrm{~g}$ pakan basal/ekor/hari $+1,5 \mathrm{~g}$ (EDP+BAL).

- dosis $2 \%=150 \mathrm{~g}$ pakan basal/ekor/hari $+3 \mathrm{~g}$ (EDP+BAL).

- dosis $3 \%=150 \mathrm{~g}$ pakan basal/ekor/hari $+4,5 \mathrm{~g}$ (EDP+BAL).

Pemeliharaan itik dimulai dengan adaptasi pakan selama 2 minggu kemudian dipelihara lagi sampai 30 minggu, pemeliharaan meliputi pemberian pakan setiap pagi dan sore hari, pemberian minum secara ad libitum, sanitasi pakan dan minum, pengecekan suhu dan kelembapan serta buka tutup tirai untuk mengatur sirkulasi udara.

Data diambil pada saat itik sudah berumur 30 minggu dengan cara sebagai berikut :

1. Itik disembelih dengan metode islami (Delfita, 2013) setiap unit percobaan satu ekor dengan bobot badan yang paling mendekati rata-rata tiap satu unit perlakuan untuk diamati organ saluran pencernaanya.

2. Bulu itik dibersihkan sampai bersih, kemudian mengeluarkan organ pencernaan dari dalam badan itik.

3. Bobot relatif saluran pencernaan dihitung dengan cara menimbang bobot ventrikulus, hati, usus halus dan sekum seletah dibersihkan dari kotoran mulai esofagus sampai kloaka di bagi dengan bobot hidup dikali 100\%.

Bobot relatif saluran pencernaan

$=\frac{\text { Bobot Saluran Pencernaan }}{\text { bobot hidup }} \times 100 \%$ 
4. Panjang jejenum, ileum, duodenum dan sekum diukur dengan cara digantung dan diukur dari ujung atas sampai bawah dari saluran pencernaan menggunakan pita ukur dalam satuan $\mathrm{cm}$.

\section{Metode Penelitian dan Analisis Data}

Metode penelitian adalah percobaan in vivo dengan menggunakan Rancangan Acak Lengkap (RAL) (Mas, 2015) yang terdiri dari 4 perlakuan dengan 4 ulangan setiap ulangan sebagai unit percobaan, sehingga terdapat 16 unit percobaan. Setiap unit percobaan terdiri dari 6 ekor itik. Setiap unit diambil satu sampel untuk dilakukan pengukuran. Data yang diperoleh dianalisis menggunakan analisis ragam dan uji Duncan. Parameter yang diamati adalah bobot relatif saluran ventrikulus, usus halus, hati, sekum serta panjang illeum, jejunum, duodenum sekum.

\section{HASIL DAN PEMBAHASAN}

\section{Bobot Saluran Pencernaan}

Berdasarkan hasil penelitian diketahui bahwa penambahan limbah EDP dan BAL tidak memberikan pengaruh nyata pada bobot saluran pencernaan. Hasil bobot relatif saluran pencernaan itik Tegal yang diberi pakan dengan tambahan kombinasi limbah EDP dan BAL ditampilkan pada Tabel 5.

Rata-rata bobot relatif usus halus yang dihasilkan tidak berbeda jauh dari penelitian yang dilakukan Jiang et al. (2012) dengan itik umur 15 minggu, penambahan alfalfa menghasilkan rata-rata bobot relatif usus halus yang mencapai 3,23 $\pm 0,17 \%$. Hasil penelitian ini tidak jauh berbeda dari penelitian Sumiyati dan Sumirat (2003), dimana bobot relatif usus halus itik lokal jantan umur 8 minggu dapat mencapai $3,61 \pm 0,12 \%$. Hasil penelitian juga tidak berbeda jauh dari penelitian Ahmed et al. (2018), bobot relatif usus halus itik mallard umur 5 minggu sebesar 3,13\%.

Pada penelitian ini, kombinasi limbah EDP dengan BAL tidak mempengaruhi bobot usus halus. Hal ini dikarenakan jumlah kombinasi prebiotik dan probiotik pada additif pakan yang diberikan belum cukup sehingga tidak mempengaruhi bobot usus. Hasil penelitian ini selaras dengan penelitian yang dilakukan oleh Iriyanti dan Hartoyo (2017) menyebutkan bahwa pemberian sinbiotik dengan dosis $2 \%, 4 \%$ dan $6 \%$ pada itik tegal jantan tidak memberikan pengaruh signifikan terhadap bobot duodenum, ileum dan jejenum.

Bobot sekum yang dihasilkan tidak jauh berbeda dari penelitian Sumiati dan Sumirat et al, (2003) yang menyatakan bobot relatif sekum itik jantan dapat mencapai $0,34 \pm 0,03 \%$. Bobot relatif sekum sama dengan rata-rata bobot itik pada umumnya. Bobot relatif sekum juga tidak berbeda jauh dari hasil penelitian Jiang et al. (2012) yang menyatakan bahwa bobot relatif sekum yang dihasilkan dapat mencapai $0,33 \pm 0,004 \%$. Bobot relatif sekum yang dihasilkan tidak jauh berbeda dari hasil penelitian Iriyanti et al. (2018) yang menyatakan bobot relatif sekum itik tegal jantan umur 7 minggu yang diberi pakan tambahan fructooligosaccharides (FOS) menghasilka rata-rata $0,41 \pm 0,5 \%$.

Hasil penelitian ini tidak selaras dari hasil penelitian yang dilakukan oleh Iriyanti et al. (2018) yang menyatakan bahwa penambahan prebiotik jenis tertentu tanpa probiotik pada taraf $0,2 \%$ dapat meningkatkan bobot sekum itik umur 7 minggu. Perbedaan ini diduga karena umur itik yang digunakan pada penelitian tersebut masih muda sehingga sekum mampu berkembang lebih baik dibanding pada itik dewasa. Saluran pencernaan cenderung berhenti berkembang pada unggas dewasa. Kokoszyński (2017) menyatakan bahwa umur adalah salah satu faktor yang dapat mempengaruhi perubahan saluran pencernaan yang menyangkut berat, panjang dan lebar.

Bobot hati pada penelitian ini tidak jauh berbeda dari penelitian yang dilakukan oleh Ahmed (2018) yang menyatakan bahwa bobot relatif hati itik yang diberi prebioik pada suhu tinggi rata-rata sebesar 2,24 $\pm 0,16$ $\%$. Hasil penelitian ini lebih rendah dari penelitian Han (2016) dengan itik pekin umur 14 hari yaitu mencapai $3,67 \%$, namun lebih tinggi dari itik pekin umur 35 hari yaitu $1,89 \%$. Perbedaan ini dikarenakan perbedaan umur dan jenis itik yang digunakan. Pertumbuhan organ pencernaan cenderung berhenti tumbuh pada umur dewasa. Dinyatakan oleh Gille et al. (1999), pertambahan bobot hati berkurang pada umur itik mencapai 20 minggu. Menurut Maradon (2015), ukuran tubuh dan genetik akan mempengaruhi bobot saluran pencernaan unggas.

Hasil penelitian ini selaras dengan penelitian yang dilakukan oleh Iriyanti dan Hartoyo (2017) yang

Tabel 5. Bobot relatif saluran pencernaan itik Tegal yang diberi pakan dengan tambahan kombinasi limbah EDP dan BAL.

\begin{tabular}{|c|c|c|c|c|}
\hline \multirow{2}{*}{ Perlakuan } & \multicolumn{4}{|c|}{ Bobot Relatif Saluran Pencernaan } \\
\hline & Usus Halus $^{\mathrm{ns}}$ & Sekum ${ }^{\mathrm{ns}}$ & Hati $^{\text {ns }}$ & Ventrikulus $^{\mathrm{ns}}$ \\
\hline & \multicolumn{4}{|c|}{ 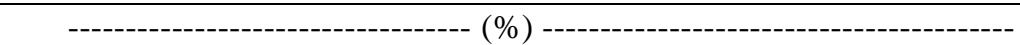 } \\
\hline T0 & $3,84 \pm 0,17$ & $0,37 \pm 0,06$ & $1,99 \pm 0,08$ & $4,38 \pm 0,14$ \\
\hline $\mathrm{T} 1$ & $3,67 \pm 0,26$ & $0,40 \pm 0,06$ & $2,12 \pm 0,32$ & $4,38 \pm 0,31$ \\
\hline $\mathrm{T} 2$ & $3,61 \pm 0,20$ & $0,39 \pm 0,08$ & $2,12 \pm 0,29$ & $4,14 \pm 0,44$ \\
\hline T3 & $3,59 \pm 0,10$ & $0,40 \pm 0,06$ & $2,27 \pm 0,24$ & $4,01 \pm 0,11$ \\
\hline Rata-rata & $3,68 \pm 0,09$ & $0,39 \pm 0,03$ & $2,13 \pm 0,14$ & $4,23 \pm 0,10$ \\
\hline
\end{tabular}

ns = not significant $(\mathrm{P}>0,05)$ 
Tabel 6. Panjang saluan pencernaan itik Tegal yang diberi pakan dengan tambahan kombinasi EDP dengan BAL.

\begin{tabular}{|c|c|c|}
\hline \multirow{2}{*}{ Perlakuan } & \multicolumn{2}{|c|}{ Panjang Saluran Pencernaan } \\
\hline & Duodenum $^{\mathrm{ns}}$ & Jejenum $^{\text {ns }}$ \\
\hline & - $(\mathrm{cm})$--------- & \\
\hline T0 & $25,25 \pm 1,90$ & $67,75 \pm 4,57$ \\
\hline $\mathrm{T} 1$ & $24,75 \pm 3,20$ & $64,25 \pm 7,89$ \\
\hline $\mathrm{T} 2$ & $26,50 \pm 2,52$ & $73,75 \pm 8,65$ \\
\hline T3 & $22,00 \pm 2,83$ & $69,50 \pm 1,00$ \\
\hline Rata-rata & $24,63 \pm 0,75$ & $69,06 \pm 1,71$ \\
\hline
\end{tabular}

menyatakan bahwa penambahan sinbiotik pada pakan sampai dengan paraf $6 \%$ tidak mempengaruhi bobot hati itik tegal jantan. Penambahan limbah EDP + BAL tidak memberikan pengaruh terhadap bobot hati. Kandungan tanin pada extrak daun pepaya masih bisa ditolerir, sehingga hati tetap bekerja optimal dengan penambahan additif sampai dengan taraf 3\%. Menurut Sulistyoningsih (2015), hati adalah organ yang berfungsi untuk menyaring zat-zat pakan dari patogen yang telah diserap sebelum masuk ke darah.

Bobot ventrikulus yang dihasilkan lebih tinggi dari penelitian yang dilakukan oleh Wasilewski et al, (2015) yang menyatakan rata-rata bobot ventrikulus pada itik betina sebesar 3,25 $\pm 0,50 \%$. Perbedaan ini dikarenakan jenis kelamin yang berbeda pada itik akan mempengaruhi bobot saluran pencernaanya. Bobot relatif ventrikulus yang dihasilkan lebih rendah dari penelitian yang dilakukan oleh Sumiyati dan Sumirat (2003) yaitu mencapai $5,6 \pm 0,13 \%$, perbedaan ini dikarenakan bahan pakan yang digunakan. Penelitian tersebut menggunakan kayambang dengan jumlah serat kasar yang lebih tinggi sehingga akan mempengaruhi kinerja ventrikulus. Dinyatakan oleh Svihus (2011), ventrikulus dipengaruhi oleh komposisi pakan yang masuk, partikel yang kasar akan menyebabkan otot ventrikulus bekerja lebih berat sehingga ventrikulus akan membesar.

Pemberian additif pada pakan dengan probiotik BAL dan prebiotik berupa limbah EDP tidak mempengaruhi bobot relatif ventrikulus. Hal ini diduga karena probiotik tidak bekerja pada ventrikulus. Menurut Svihus (2002), ventrikulus berfungsi untuk memecahkan pakan menjadi bagian yang lebih kecil dengan cara mekanis. Kandungan oligosakarida pada limbah EDP yang digunakan yaitu rentang 3,14\% sampai 3,46\% sebagai prebiotik pada penelitian tidak berpengaruh pada kinerja ventrikulus. Sutrisna (2011) menyatakan bahwa penambahan serat kasar dengan selisih 5\% mempengaruhi bobot ventrikulus.

Penambahan limbah EDP + BAL dengan dosis mencapai $3 \%$ belum mempengaruhi bobot saluran pencernaan. Hal ini dikarenakan BAL tidak bekerja pada semua organ pencernaan. Menurut Garcia-Amado et al. (2018) ventrikulus bekerja secara mekanik untuk menghaluskan pakan. Selain itu, umur itik juga dapat mempengaruhi bobot relatif saluran pencernaan. umur semakin bertambah ukuran tubuh bisa berubah bertambah besar atau berhenti berkembang. Patrick dan
Schaible (1980) menyatakan pertumbuha saluran pencernaan secara menyeluruh dipengaruhi oleh genetik, umur, kualitas ransum, kondisi lingkungan dan kesehatan.

\section{Panjang Saluran Pencernaan}

Berdasarkan hasil penelitian, penambahan additif pakan limbah EDP yang dikombinasikan dengan BAL tidak memberikan pengaruh nyata pada panjang saluran pencernaan (Tabel 6).

Panjang duodenum pada penelitian ini tidak berbeda jauh dari hasil penelitian Allaily (2017) yang menyatakan panjang duodenum pada itik indramayu umur 32 minggu yang diberi pakan fermentasi memilki rata-rata $24 \mathrm{~cm}$. Panjang jejenum yang dihasilkan tidak jauh dari penelitian yang dilakukan oleh Han (2016) panjang Jejenum pada itik pekin jantan umur 35 hari dapat mencapai $72,58 \mathrm{~cm}$. Panjang illeum tidak jauh berbeda dari penelitian Kokoszýnski et al. (2018) yang menyatakan panjang ileum itik persilangan mallard dengan pekin umur 110 minggu mencapai $68,1 \mathrm{~cm}$.

Pemberian probiotik akan mempengaruhi panjang usus halus, karena probiotik akan mengatur keseimbangan mikrobakterial pada usus halus. Sesuai dengan pendapat Zurmiati (2014) yang menyatakan pemberian probiotik pada itik akan memberikan pengaruh yang baik salah satunya dapat meningkatkan lactobacillus sampai $8,3 \%$. Pada penelitian ini, pemberian kombinasi limbah EDP dengan BAL tidak mempengaruhi panjang usus halus. Hal ini disebabkan jumlah yang diberikan jumlahnya masih kurang. Hasil penelitian ini selaras dengan hasil penelitian dari Iriyanti dan Hartoyo (2017) yang menyatakan pemberian sinbiotik pada taraf $6 \%$ dari pakan basal tidak berpengaruh nyata terhadap panjang duodenum, jejenum dan ileum.

Panjang sekum yang dihasilkan tidak jauh berbeda dari penelitian yang dilakukan oleh Allaily et al. (2017) menyatakan panjang sekum pada itik dapat mencapai 14,95 $\pm 1,23 \mathrm{~cm}$. Panjang sekum tidak jauh berbeda dari penelitian Han (2016) panjang sekum pada itik pekin jantan umur 35 hari dapat mencapai 15,6 \pm $0,58 \mathrm{~cm}$. Denbow (2015) menyatakan panjang sekum itik lokal dapat mencapai $14 \mathrm{~cm}$ yang dapat berubah sesuai lingkungan tempat itik hidup. Berdasarkan hasil perhitungan analisis ragam, pemberian kombinasi EDP dengan BAL sebagai pakan additif tidak mempengaruhi panjang sekum itik. Faktor umur pada 
itik yang digunakan diduga mempengaruhi pertumbuhan panjang sekum. Menurut Gille et al. (1999), pertumbuhan organ saluran pencernaan pada itik mallard dapat optimum sampai umur 14 hari kemudian akan mengalami penurunan kecepatan pertumbuhan.

Selain umur, bentuk pakan, kandungan nutrisi ransum juga akan mempengaruhi panjang saluran pencernaan. bentuk pakan yang digunakan setiap perlakuan hampir sama sehingga belum mempengaruhi panjang saluran pencernaan. Yang et al. (2013), bentuk pakan, hardness, Solubility dan aktivitas enzim dapat mempengaruhi ukuran saluran pencernaan. kandungan nutrisi yang diberikan tidak berbeda jauh pada tiap perlakuan sehingga tidak mempengaruhi ukuran panjang saluran pencernaan. Dinyatakan oleh Svihus (2011), komposisi kandungan ransum dapat mempengaruhi ukuran saluran pencernaan. pemberian additif dinilai masih rendah sehingga tidak mempengaruhi panjang saluran pencernaan namun dapat memepengaruhi performa yang dilihat dari pertambahan bobot badan awal produksi.

\section{KESIMPULAN}

Berdasarkan penelitian ini, penambahan kombinasi limbah Ekstraksi Daun Pepaya (EDP) dengan Bakteri Asam Laktat (BAL) dengan taraf 0\%, $1 \%, 2 \%$ dan $3 \%$ sebagai additif pakan pada itik tegal betina umur 22 sampai 30 minggu tidak memberi pengaruh buruk, sehingga additif pakan bisa digunakan. Pemberian additif tidak mengakibatkan menambahnya panjang dan bobot saluran pencernaan itik tegal betina.

\section{DAFTAR PUSTAKA}

Ahmed, M. M. N., Z. S. H. Ismail dan A. A. A. AbdelWareth. 2018. Effect of dietary supplementation of prebiotic, betaine and their combination on growth performance, nutrient digestibility, carcass criteria and cecum microbial population of ducks under hot environmental conditions. Egyptian Poultry Science Journal 38(1): 289304.

Allaily., R. Muhammad, A. Y. Muhammad, S. Agus dan Nahrowi. 2017. Profil darah, organ pencernaan dan kandungan amonia feses itik petelur yang diberi pakan fermentasi. Buletin Peternakan. 41(2): 126-133.

Astuti, F. K. 2015. Pengaruh penambahan probiotik cair dalam pakan terhadap penampilan produksi ayam pedaging. Jurnal Pembangunan dan alam Lestari. 6(2): 99 - 104.

Badan Pusat Statistik. 2018. Statistik Peternakan. BPS, Jakarta.

Bandyopadhyay, B. dan N. C. Mandal. 2014. Probiotics, prebiotics and synbiotics-in health improvement by modulating gut microbiota: The concept revisited. International Journal of
Current Microbiology and Applied Sciences 3(3): 410-420.

Dankowiakowska, A., I. Kozłowska dan M. Bednarczyk. 2013. Probiotics, prebiotics and synbiotics in poultry - mode of action, limitation, and achievements. Journal of Central European Agriculture14(1): 467-478.

Delfita, R. 2013. Evaluasi teknik pemotongan ayam ditinjau dari kehalalan dan keamanan pangan di kabupaten Tanah Datar. Jurnal Saintek. 5(1): 78 $-87$.

Denbow, D. M. 2015. Sturkie's Avian Physiology (The Sixth Edition). Elsevier Inc., New York.

Gille, U., F. V. Salomon dan J. Ronnert. 1999. Growth of the digestive organs in ducks with considerations on their growth in birds in general. British Poultry Science 40(2): 194-202.

Han, H., K. Zhang, X. Ding, S. Bai, Y. Luo, J. Wang, H. Peng dan Q. Zeng. 2016. Effects of dietary nanocrystalline cellulose supplementation on growth performance, carcass traits, intestinal development and lipid metabolism of meat ducks. Animal Nutrition 6(4): 1-6.

Iriyanti, N., B. Hartoyo dan S. Suhermiyati. 2018. Performance and intestinal profiles of tegal duck fed ration supplemented with prebiotics. Tropical Animal Science Journal 41(1): 15-21.

Irriyanti, N dan B. Hartoyo. 2017. Effect of synbiotics supplementation in feed on tegal male duck's internal organs. Animal Production. 19(1): 2935.

Jiang, J. F., X. M. Song, X. Huang, W. D. Zhou, J. L. Wu, Z. G. Zhu1, H. C. Zheng dan Y. Q. Jiang. 2012. Effects of alfalfa meal on growth performance and gastrointestinal tract development of growing ducks. AsianAustralasian Journal of Animal Sciences 25(10): 1445-1450.

Khalili, R. M. A., A. Abdullah dan A. Manaf. 2014. Isolation and characterization of oligosaccharides composition in organically grown red pitaya, white pitaya and papayaInternational Journal of Pharmacy and Pharmaceutical Sciences 6(2): 131-136.

Kim, J. S., S. L. Ingale, Y. W. Kim, K. H. Kim, S. Sen, M. H. Ryu, J. D. Lohakare, I. K. Kwon dan B. J. Chae. 2012. Effect of supplementation of multimicrobe probiotic product on growth performance, apparent digestibility, cecal microbiota and small intestinal morphology of broilers. Journal of Animal Physiology and Animal Nutrition 96(4): 618-626.

Kompiang, I. P. 2009. Pemanfaatan mikroorganisme sebagai probiotik untuk meningkatkan produksi ternak unggas di Indonesia. Jurnal Pengembangan Inovasi Pertanian. 2(3): 177191.

Kokoszyński, D., Z. I. Bernacki, M. Saleh, K. Stęczny and M. Binkowska. 2017. Body conformation and internal organs characteristics of different 
commercial broiler lines. Brazilian Journal of Poultry Science 19(1): 047-052.

Kokoszyński, D., M. Saleh, B. Zenon, M. Kotowicz, J. Zochowska-Kujawska dan K. Stęczny. 2018. Digestive tract morphometry and breast muscle microstructure in spent breeder ducks maintained in a conservation programme of genetic resources. Animal Breeding 61(3): 373378.

Maradon, G. G., S. Rudy dan Erwanto. 2015. Pengaruh ransum dengan kadar serat kasar berbeda terhadap organ dalam ayam jantan tipe medium umur 8 minggu. Jurnal Ilmiah Peternakan Terpadu. 3(2): 6-11.

Mas, I. K. G. Y. 2015. Analisis Statistika Dalam Percobaan Satu Faktor untuk Ilmu Peternakan. Media Inspirasi Semesta, Semarang.

Mountzouris, K. C., Tsitrsikos, Palamidi, Arvaniti, Mohnl, Schatzmayr dan K. Fegeros. 2010. Effects of probiotic inclusion levels in broiler nutrition on growth performance, nutrient digestibility, plasma immunoglobulins, and cecal microflora composition. Poultry Science 89(1): 58-67.

Patrick, H., dan P. J. Schaible. 1980. Poulry Feeds and Nutrition. 2nd Ed. Avi Publising Company Inc, Westport.

Peraturan Menteri Pertanian Republik Indonesia Nomor 14/Permentan/PK.350/5/2017 tentang Klasifikasi Obat Hewan.

Singh, G., A. Kour dan G. P. Pathak. 2014. Impact of environmental factors on production and reproduction in domestic animals. Journal of Agriculture and Veterinary Sciences 7(2): 1012.

Sulistyoningsih, M. 2015. Pengaruh variasi herbal terhadap organ dalam broiler. Seminar Nasional Konversi dan Pemanfaatan Sumber Daya Alam. Universitas Negeri Surakarta, Surakarta, 13 Januari 2015.

Sumiyati dan A. Sumirat. 2003. Persentase bobot saluran pencernaan dan organ dalam itik lokal (Anas platyrhyncos) jantan yang diberi berbagai taraf kayambang (Salvinia molesta) dalam ransumnya. Jurnal Media Peternakan. 26(1): 1116.

Suprijatna, E., D. Sunarti, U. Atmomarsono dan W. Sarengat. 2012. Prosiding Workshop Nasional Unggas Lokal 2012. Puslitbang Peternakan : 2433

Sutrisna, R. 2011. Pengaruh beberapa tingkat serat kasar dalam ransum terhadap pekembangan organ dalam itik jantan. Jurnal Penelitian Pertanian Terapan. 12(1): 1-5.

Svihus, B. 2014. Function of the digestive system. The Journal of Applied Poultry Research 23: 306314.
Tamzil, M. H. 2014. Stres panas pada unggas: metabolisme, akibat dan upaya penanggulangannya. Wartazoa. 24(2): 57-66.

Wasilewski, R., D. Kokoszyński, A. Mieczkowska, Z. Bernacki dan A. Górska. 2015. Structure of the digestive system of ducks depending on sex and genetic background. Acta Veterinaria Brno 84(2): 153-158.

Wichienchot, S., P. Thammarutwasik, A. Jongjareonrak, W. Chansuwan, P. Hmadhlu, T. Hongpattarakere, A. Itharat dan B. Ooraikul. 2011. Extraction and analysis of prebiotics from selected plants from Southern Thailand. Journal of Science and Technology 33(5): 517-523.

Wijaya, Y., E. Suprijatna dan S. Kismiati. 2017. Penggunaan limbah industri jamu dan bakteri asam laktat (Lactobacillus sp.) sebagai sinbiotik untuk aditif pakan terhadap kualitas interior telur ayam ras petelur. Jurnal Peternakan Indonesia. 19(2): 46-53.

Yang, H. M., W. Wang, Z. Y. Wang, J. Wang, Y. J. Cao dan Y. H. Chen. 2013. Comparative study of intestine length, weight and digestibility on different body weight chickens. African Journal of Biotechnology 12(32): 5097-5100.

Zurmiati, M. E. Mahata, M. H. Abbas dan Wizna. 2014. Aplikasi Probiotik Untuk Ternak Itik. Jurnal Peternakan Indonesia 16(2): 134-144. 